\title{
Gallbladder Neurofibroma
}

National Cancer Institute

\section{Source}

National Cancer Institute. Gallbladder Neurofibroma. NCI Thesaurus. Code C5746.

A non-metastasizing encapsulated neoplasm arising from nerves in the gallbladder.

Morphologically, it is characterized by the presence of fibroblasts and Schwann cells. 